\title{
DAMPAK PENERAPAN ABSENSI FINGER PRINT DENGAN KEDISIPLINAN PEGAWAI DI UPTD PASAR KAUMAN KABUPATEN TULUNGAGUNG
}

\section{THE USE OF THE FINGER PRINT TO IMPROVE THE DICIPLINE OF OFFICIAL SERVANTS AT UPTD PASAR KAUMAN, TULUNGAGUNG REGENCY}

\author{
Nunun Nurhajati, Cicik Malinda
}

\begin{abstract}
Program Studi Administrasi Publik, Fakultas Ilmu Sosial dan Ilmu Politik,Universitas Tulungagung, Tulungagung, Indonesia

Program Studi Administrasi Publik, Fakultas Ilmu Sosial dan Ilmu Politik,Universitas Tulungagung, Tulungagung, Indonesia
\end{abstract}

nununnurhajati@gmail.com, cicikmalinda77@gmail.com

\begin{abstract}
ABSTRAK
Dalam rangka mendisiplinkan pegawainya, kepala UPTD Pasar Kauman, menerapkan sistem absensi online Finger Print. Dikarenakan selama ini pada absensi manual (hanya berupa buku daftar hadir), kepala sekolah dan pegawai yang melihat absensi, tidak bisa mengetahui tingkat kedisiplinan pegawai lain. Sebab pada absensi manual, pegawai dapat memanipulasi data absensi, seperti bisa merapel di hari lain atau menitip absen pada pegawai lain. Sehingga sistem absensi Finger Print ini diterapkan sebagai perwujudan perbaikan penggunaan absensi manual yang dianggap tidak efektif dan efisien dalam penerapannya.
\end{abstract}




\section{Nunun Nurhajati, Cicik Malinda}

Dampak Penerapan Absensi Finger Print Dengan Kedisiplinan Pegawai Di Uptd Pasar Kauman

Kabupaten Tulungagung

Dalam penelitian ini, metode penelitian yang digunakan yaitu metode kualitatif dengan jenis pendekatan deskriptif. Lalu, tekhnik pengumpulan data yang dipakai adalah Wawancara, Observasi dan Dokumentasi. Hasil analisis data menunjukkan sebagai berikut: (1)Dampak Penerapan Absensi Finger Print dengan Peningkatan Kedisiplinan Pegawai di UPTD Pasar Kauman Kabupaten Tulungagung, sebagai berikut:

(a) Ketepatan Jam Kerja, (b) Kepatuhan pegawai, (c) Penyelesaian Tugas, (d) Mematuhi peraturan dalam bekerja. (2) Faktor Yang Mendukung dan Faktor Yang Menghambat dengan Penerapan Absensi Finger Print dalam Peningkatan Kedisiplinan Pegawai di UPTD Pasar Kauman Kabupaten Tulungagung, antara lain: (a) Faktor Pendukung: Sarana dan Prasarana yang sudah memadahi dengan adanya mesin finger print yang sudah tersedia, Peraturan dari Dinas yang mendukung, Sumber Daya Manusia (SDM) yang mumpuni, (b) Faktor Penghambat: Connect Internet (Jaringan Internet) yang masih sedikit lelet, efisiensi waktu yang masih belum maksimal apabila terjadi kerusakan pada mesin finger print.

\section{Kata Kunci : Dampak, Absensi Finger Print, Disiplin Pegawai}

\section{ABSTRACT}

In order to discipline its employees, the head of the UPTD Pasar Kauman, implements the Finger Print online attendance system. Due to manual attendance so far (only in the form of an attendance list), school principals and employees who see attendance cannot know the level of discipline of other employees. Because in manual attendance, employees can manipulate attendance data, such as being able to make appointments on other days or leave absences to other employees. So that the Finger Print attendance system is implemented as an embodiment of improving the use of manual attendance which is considered ineffective and efficient in its application. 
PUBLICIANA : JURNAL ILMU SOSIAL DAN ILMU POLITIK

VOLUME 14 NO 1

ISSN : $1979-0295$ | E-ISSN : $2502-7336$

In this study, the research method used is a qualitative method with a descriptive approach.

Then, the data collection techniques used are Interview, Observation and Documentation. The results of data analysis show the following: (1) The Impact of Finger Print Attendance Implementation in Increasing Employee Discipline at UPTD Pasar Kauman, Tulungagung Regency, as follows:

(a) Punctuality in Working Hours, (b) Employee Compliance, (c) Task Completion, (d) ) Comply with the rules at work. (2) Supporting and Inhibiting Factors in the Implementation of Finger Print Attendance in Improving Employee Discipline at UPTD Pasar Kauman, Tulungagung Regency, among others:

(a) Supporting Factors: Adequate facilities and infrastructure with finger print machines available, Regulations from the Office that support, qualified Human Resources (HR), (b) Inhibiting Factors: Connect Internet (Internet network) which is still a bit slow, time efficiency is still not maximized if there is damage to the finger print machine.

\section{Keywords: Linkage, Finger Print Attendance, Employee Discipline}

\section{PENDAHULUAN}

Salah satu perkembangan teknologi informasi yang penting adalah semakin dibutuhkannya penggunaan alat pengolah data yang berfungsi untuk menghasilkan informasi yang dibutuhkan. Perusahaan-perusahaan yang ingin mengembangkan usaha dan mencapai sukses harus mengikuti era informasi dengan menggunakan alat pendukung pengolah data yaitu komputer.

Peran sistem informasi pada dasarnya adalah proses komunikasi yang mengandung transformasi pengetahuan, nilai-nilai, dan keterampilan-keterampilan di luar lingkungan. Jika sistem informasi diterapkan dalam dunia kepegawaian maka akan terjalin suatu relasi atau 


\section{Nunun Nurhajati, Cicik Malinda}

Dampak Penerapan Absensi Finger Print Dengan Kedisiplinan Pegawai Di Uptd Pasar Kauman

Kabupaten Tulungagung

hubungan yang membawa dampak positif bagi dunia kepegawaian itu sendiri. Salah satu dampak positif dari penerapan sistem yaitu kedisiplinaan.

Displin bukan hanya tepat waktu saja, tetapi juga patuh pada peraturan-peraturan yang ada. Melaksanakan yang diperintahkan dan meninggalkan segala yang dilarang. Disamping itu juga melakukan perbuatan tersebut secara teratur dan terus menerus walaupun hanya sedikit. Karena selain bermanfaat bagi diri sendiri. Seiring dengan perkembangan Teknologi Informasi memacu suatu cara baru dalam kehidupan, dari kehidupan dimulai sampai dengan berakhir, kehidupan seperti ini dikenal dengan elife, artinya kehidupan ini sudah dipengaruhi oleh berbagai kebutuhan secara elektronik, elaboratory, e-biodiversitiy, dan yang lainnya lagi yang berbasis elektronika. Menurut Bangun (2012:14):

"menyatakan suatu kemajuan dalam bidang ilmu dan pengetahuan yang menuntut masyarakat lebih kreatif dan aktif mengikuti perkembangan pasar adalah tehnologi”.

Seiring perkembangan teknologi informasi di masyarakat. Secara tidak langsung, teknologi mengubahcara kita hidup dan bekerja. Kemajuan teknologi perlu perlindungan menyeluruh akan informasi jati diri kita agar tidak disalahgunakan untuk keperluankeperluan yang mengganggu. Robbins and Coulter (2010:91) menyatakan:

'’Perubahan teknologi telah menjadi sumber penting dari ketidakpastian lingkungan yang dihadapi organisasi, perubahan teknologi ini juga memungkinkan para pemimpin untuk mengkoordinasi usaha kerja para karyawan dengan cara lebih efisien dan efektif'” 
Selanjutnya Sutrisno (2015:5) menyatakan:

"pengembangan dan pemanfaatan pegawai dalam rangka tercapainya tujuan dan sasaran individu, organisasi, masyarakat, bangsa dan internasional yang efektif merupakan arti dari Sumber Daya Manusia ( SDM )”.

Dari beberapa pengertian para ahli di atas, bisa ditarik sebuah kesimpulan mengenai apa yang dimaksud dengan Sumber daya Manusia yaitu sebuah perencanaan, pengorganisasian,pergerakan dan pengawasan atas pengadaan, pengembangan, kompensasi, pengintegrasian, pemeliharaan dan pemutusan hubungan kerja dengan maksud untuk pencapaian tujuan organisasi perusahaan secara terpadu.

Kedisiplinan salah satu kajian dan fungsi terpenting dalam Sumber Daya Manusia (SDM) karena semakin baik disiplin karyawan, semakin tinggi pula prestasi kerja yang dapat dicapainya. Tanpa disiplin kerja yang baik, sulit bagiorganisasi perusahaan mencapai hasil yang optimal. Maka dari itu, kedisplinan selalu dijadikan salah satu bahan untuk menilai kinerja seorang pegawai.

Guna mengetahui kehadiran pegawai UPTD Pasar Kauman, diperlukan sistem absensi yang dapat mencatat seluruh kehadiran. Fitranto, menjelaskan absensi adalah suatu kegiatan yang bertujuan untuk mengetahui tingkat prestasi kehadiran sertatingkat kedisiplinan dari anggota dalam suatu instansi, institusi atau perusahaan. Sedangkan menurut Supriatna (2008:45), absensi mengandung pemahaman sebagai suatu bentuk kehadiran seseorang di sebuah tempat untuk memenuhi kewajibannya.

Berdasarkan pengertian diatas dapat diketahui absensi adalah suatu kegiatan pencatatan kehadiran untuk mengetahui kinerja sesorang dalam menjalankan tugas dan 


\section{Nunun Nurhajati, Cicik Malinda}

Dampak Penerapan Absensi Finger Print Dengan Kedisiplinan Pegawai Di Uptd Pasar Kauman

Kabupaten Tulungagung

kewajibannya di suatu lembaga atau perusahaan. Jadi adanya system absensi untuk mencegah adanya kegiatan titip absen.

Untuk menciptakan kedisiplinan pegawai salah satunya adalah dengan meningkatkan absensi pegawai. Absensi pegawai ini juga merupakan parameter dari kedisiplinan pegawai. Oleh sebab itu organisasi harus menciptakan disiplin kerja yang tinggi dalam rangka pencapaian tujuan. Karena disiplin dalam pekerjaan sangat penting bagi suatu organisasi, sebab tanpa disiplin tidak akan ada usaha bersama yang konstruktif di dalam nencapai tujuan bersama. Sehingga penerapan disiplin yang tinggi merupakan salah satu cara untuk membentuk sumber daya manusia yang berkualitas.

Absensi merupakan ketidak hadiran pegawai saat yang bersangkutan dijadwalkan bekerja. Jumlah absen kerja dalam perusahaanatau instansi menggambarkan pertukaran benefit antara karyawan dan perusahaan yang menggaji. Ada tiga ukuran absen, yaitu hilangnya waktu kerja, frekuensi atau tingkat keseringan absen, dan jumlah absen dalam jangka pendek. Menurut Nugroho dalam Santoso dan Yulianto (2017:67) menyatakan bahwa absensi merupakan sebuah pembuatan data untuk daftar kehadiran yang biasa digunakan bagi sebuah lembaga atau instansi yang sangat perlu membutuhkan sistem seperti ini.

Absensi biometrik yang banyak digunakan pada organisasi perusahaan adalah absensi biometrik sidik jari (finger print). Finger print adalah salah satu bentuk biometrik, sebuah ilmu yang menggunakan karakteristik fisik untuk mengidentifikasi. Sidik jari sangat ideal untuk tujuan inikarena tergolong lebih murah/mudah dijangkau, mudah untuk mengumpulkan dan menganalisis serta tidak pernah berubah, bahkan dengan umur orang. Pada sistem presensi dengan biometric 
PUBLICIANA : JURNAL ILMU SOSIAL DAN ILMU POLITIK

VOLUME 14 NO 1

ISSN : $1979-0295$ | E-ISSN : $2502-7336$

finger print tingkat kecurangan yang sering terjadi seperti manipulasi data dan penitipan absensiakan dapat dikurangi. Kurangnya pengawasan dalam penggunaan sistem presensi fingerprint dapat mempengaruhi tingkat efektivitas dari laporan yang dihasilkan. Adanya informasi yang tidak akurat dapat menjadi salah satu indikator bahwasistem presensi dengan biometric finger print belum terimplementasi dengan baik.

Sebagaimana telah diatur di dalam peraturan nomor53 tahun 2010 tentang disiplin Pegawai Negeri Sipil, menyatakan:

”Dimana DisiplinPegawai Negeri Sipil merupakan kesanggupan Pegawai Negeri Sipiluntuk menaati kewajiban dan menghindari larangan yang ditentukan dalam peraturan perundang-undangan dan/atau peraturan kedinasan yang apabila tidak ditaati atau dilanggar dijatuhi hukuman disiplin. Apabila tingkat kedisiplinan pegawai rendah maka pegawai tersebut tidak mendapatkan kompensasi berupa uang makan”.

Oleh sebab itu, Dinas Perindustrian dan Perdagangan Kabupaten Tulungagung merupakan salah satu Dinas di Kabupaten Tulungagung yang memiliki banyak personil Pegawai Negeri Sipil, dimana sudah menerapkan aplikasi sistem absensi biometrik sidik jari (finger print) di setiap UPTD-nya, dengan harapan dapat meningkatkan disiplin kerja pegawinya.

Pada penelitian ini, penulis menerapkan dampak penerapan absensi sidik jari (finger print) dalam peningkatan kedisiplinan pegawai pada lembaga instansi pemerintah Dinas Perindustrian dan Perdagangan Kabupaten Tulungagung. Pada kenyataannya masihbanyak pegawai yang melakukan pelanggaran. Dilihat dari data di UPTD Pasar Kauman Kabupaten Tulungagung menunjukkan masih ada beberapa pelanggaran mengenai absensi pegawai. 


\section{Nunun Nurhajati, Cicik Malinda}

Dampak Penerapan Absensi Finger Print Dengan Kedisiplinan Pegawai Di Uptd Pasar Kauman Kabupaten Tulungagung

Hal ini menunjukkan tingkat kedisiplinan pegawai atau karyawan perlu dipertanyakan. Padahal dampak penerapan absensi finger print di UPTD Pasar Kauman Kabupaten Tulungagung sudah cukup lama, akan tetapi dampak penerapan absensi finger print tidak berjalan efektif karena masih banyak pegawai yang tidak disiplin jam kerjanya atau korupsi waktu.

\section{KERANGKA TEORI}

\section{DAMPAK}

Menurut Jayakusuma (dalam Sidaruk, 2011), hubungan adalah suatu kegiatan tertentu yang membawa akibat kepada kegiatan yang lain. Selain itu arti kata hubungan dapat juga dikatakan sebagai suatu proses, cara atau arahan yang menentukan atau menggambarkan suatu obyek tertentu yang membawa dampak atau pengaruh terhadap obyek lainnya. Berdasarkan definisi di atasm maka yang dimaksud dengan dampak (hubungan) dalam penelitian iniadalah suatu keadaan saling dampak, saling mempengaruhi dan saling ketergantungan antara absensi sidik jari (finger print) dengan peningkatan kedisiplinan pegawai.

Menurut pendapat Yukl sebagaimana dikutip oleh Sumartono (2015) ada beberapa jenis dampak (hubungan) organisasional, yaitu:

a. Dampak (hubungan) dominasi artinya dalam melaksanakan hubungan tersebut pihak pertama menguasai pihak kedua.

b. Dampak (hubungan) subordinasi artinya dalam melaksanakan hubungan tersebut pihak kedua menguasai pihak pertama, atau pihak kedua dengan sengaja menempatkan diri tunduk pada kemauan pihak pertama. 
PUBLICIANA : JURNAL ILMU SOSIAL DAN ILMU POLITIK

VOLUME 14 NO 1

ISSN : $1979-0295$ | E-ISSN : $2502-7336$

c. Dampak (hubungan) kemitraan artinya pihak pertama dan kedua selevel dimana mereka bertumpu pada kepercayaan, kerjasama dan saling menghargai.

\section{IMPLEMENTASI (Penerapan)}

Menurut Usman (2013:25), penerapan (implementasi) adalah bermuara pada aktivitas, aksi, tindakan, atau adanya mekanisme suatu sistem. Implementasi bukan sekedar aktivitas, tetapi suatu kegiatan yang terencana dan untuk mencapai tujuan kegiatan.

Lebih lanjut menurut Setiawan (2014:53) penerapan (implementasi) adalah perluasan aktivitas yang saling menyesuaikan proses interaksi antara tujuan dan tindakan untuk mencapainya serta memerlukan jaringan pelaksana, birokrasi yang efektif.

\section{ABSENSI SIDIK JARI ( FINGER PRINT)}

Sidik jari merupakan guratan yang terdapat pada kulit ujung jari manusia. Sifat sidik jari pada manusia adalah unik (beda). Artinya tidak ada orang di dunia ini yang mempunyai identitas sidik jari yang sama persis.

Pelacak sidik jari atau otentikasi sidik jari mengacu pada metode otomatis memverifikasi sebuah kecocokan antara dua sidik jari manusia. Saat ini teknologi yang digunakan pada mesin sidik jari yaitu menggunakan teknologi biometrik. Menurut Faisal (2015), pelaksanaan pengisian daftar hadir atau absensi secara manual (hanya berupa buku daftar hadir), akan menjadikan penghambat bagi organisasi untuk memantau kedisiplinan pegawai dalam hal ketepatan waktu kedatangan dan jam pulang setiap hari. Hal tersebut dikhawatirkan akan membuat komitmen pegawai terhadap pekerjaan dan organisasi menjadi berkurang. 


\section{Nunun Nurhajati, Cicik Malinda}

Dampak Penerapan Absensi Finger Print Dengan Kedisiplinan Pegawai Di Uptd Pasar Kauman Kabupaten Tulungagung

Berkurangnya komitmen pegawai dalam bekerja akan berdampak pada motivasi dan kinerja karyawan yang semakin menurun. Selanjutnya Cahyana dan Maoloni (2015:34), menyatakan bahwa:

"Pencatatan absensi pegawai merupakan salah satu faktor penting dalam pengelolaan Sumber Daya Manusia ( SDM atau Human Resources Management). Informasi yang mendalam dan terperinci mengenai kehadiran seorang karyawan dapat menentukan prestasi kerja seseorang, gaji/upah, produktivitas, dan kemajuan instansi/lembaga secara umum”.

Ada beberapa teknologi biometrik yang digunakan yaitu suara, sidik jari, tangan, retina dan bentuk wajah. Menggunakan mesin biometrik absensi sidik jari (finger print), untuk absensi suatu pilihan yang tepat dibanding yang lain. Mesin finger print merupakan sistem informasi manajemen yang mengandung elemen-elemen fisik seperti yang diungkapkan oleh Davis mengenai sistem informasi manajemen (Widyahartono dalam Maisaroh, 2010) adalah sebagai berikut:

a. Perangkat keras komputer, terdiri atas komputer (pusat pengolahan, unit masukan atau keluaran, unit penyimpanan, file dan peralatan penyimpanan data).

b. Data base (data yang tersimpan dalam media penyimpanan komputer).

c. Prosedur, komponen fisik karena prosedur disediakan dalam bentuk fisik, seperti buku panduan dan instruksi.

d. Personalian pengoperasian, seperti operator komputer, analisis system pembuatan program, personalia penyimpanan data, pimpinan system informasi. 


\section{KEDISIPLINAN}

\subsection{Peningkatan Kedisiplinan}

Secara umum, peningkatan merupakan upaya untuk menambah derajat, tingkat, dan kualitas maupun kuantitas. Peningkatan juga dapat berarti penambahan keterampilan dan kemampuan agar menjadi lebih baik. Selain itu, peningkatan juga berarti pencapaian dalam proses, ukuran, sifat, hubungan dan sebagainya. Kata peningkatan juga dapat menggambarkan perubahan dari keadaan atau sifat yang negative berubah menjadi positif. Sedangkan hasil dari sebuah peningkatan dapat berupa kuantitas dan kualitas. Kuantitas adalah jumlah hasil dari sebuah proses atau dengan tujuan peningkatan. Sedangkan kualitas menggambarkan nilai dari suatu objek karena terjadinya proses yang memiliki tujuan berupa peningkatan. Hasil dari suatu peningkatan juga ditandai dengan tercapainya tujuan pada suatu titik tertentu. Dimana saat suatu usaha atau proses telah sampai pada titik tersebut maka akan timbul perasaan puas dan bangga atas pencapaian yang telah diharapkan. Hanifah (2013) menyatakan bahwa:

"Kedisiplinan merupakan suatu hal yang sangat mutlak dalam kehidupan manusia, karena seorang manusia tanpa disiplin yang kuat akan merusak sendisendi kehidupannya, yang akan membahayakan dirinya dan manusia lainnya, bahkan alam sekitarnya”.

Kedisiplinan memiliki pengertian yang berbeda-beda, untuk mendapatkan gambaran dan pengertian yang jelas tentang kedisiplinan, berikut dikemukakan pengertian disiplin menurut beberapa ahli yaitu Kenneth W. (2012) menyatakan bahwa:

"Pengertian disiplin secara konvensional mengajarkan bahwa hadiah adalah pendorong terbaik dalam membantu individu untuk melakukan sesuatu yang lebih baik. Dan salah satu prinsip pembentuk disiplin adalah mengajari seseoarang untuk melakukan hal yang benar agar memperoleh perasaan 


\section{Nunun Nurhajati, Cicik Malinda}

Dampak Penerapan Absensi Finger Print Dengan Kedisiplinan Pegawai Di Uptd Pasar Kauman Kabupaten Tulungagung

yang nyaman yang hakiki saat melakukan sesuatu dan memberikan kontribusi kepada masyarakat”.

Disiplin tidak sama dengan hukum, karena hokum adalah sesuatu yang menyakitkan atau menghina yang dilakukan orang yang lebih berkuasa kepada orang yang kurang berkuasa dengan harapan akan menghasilkan perubahan perilaku. Sikap dan perilaku demikain ini tercipta melalui proses binaan melalui keluarga, pendidikan dan pengalaman atau pengenalan keteladanan dari lingkungannya. Disiplin akan membuat dirinya tahu dan membedakan hal-hal apa yang seharusnya dilakukan, yang wajib dilakukan, yang boleh dilakukan, yang tidak sepatutnya dilakukan (karena merupakan hal-hal yang dilarang). Disiplin juga merupakan suatu kondisi yang tercipta dan terbentuk melalui proses dari serangkaian perilaku yang menunjukkan nilai-nilai ketaatan, kepatuhan, kesetiaan dan ketertiban. Karena sudah menyatu dengan dirinya, maka sikap atau perbuatan yang dilakukan bukan lagi atau sama sekali tidak dirasakan sebagai beban, bahkan sebaliknya akan membebani dirinya bilamana ia tidak berbuat sebagaimana lazimnya. Nilainilai kepatuhan telah menjadi bagian dari perilaku dalam kehidupannya(Santoso,2015).

\subsection{Aspek-aspek Kedisiplinan}

Menurut Nitisemito (2015:58) kedisiplinan memiliki 3 (tiga) aspek. Ketiga aspek tersebut adalah:

a. Aspek pemahaman terhadap peraturan yang berlaku

Sebelum mematuhi suatu peraturan perlu diketahui apakah karyawan sudah mengetahui atau memahami standar atau peraturan dengan jelas. Seorang karyawan menunjukkan kedisiplinan yang baik bila perilakunya menunjukkan usaha-usaha untuk memahami secara jelas suatu peraturan, berarti karyawan secara proaktif berusa hamen 
PUBLICIANA : JURNAL ILMU SOSIAL DAN ILMU POLITIK

VOLUME 14 NO 1

ISSN : $1979-0295$ | E-ISSN : $2502-7336$

dapatkan informasi tentang peraturan sehingga karyawan akan rajin mengikuti briefing, membaca pengumuman atau menanyakan ketidakjelasan suatu peraturan.

b. Aspek kepatuhan dan ketaatan terhadap aturan standar

Karyawan mempunyai disiplin tinggi jika tidak memiliki catatan pelanggaran selama kerjanya, mentaati suatu peraturan tanpa ada paksaan dan secara sukarela dapat menyesuaikan diri dengan aturan organisasi yang telah ditetapkan. Senantiasa menghargai waktu sehingga membuat bekerja tepat waktu, tahu kapan memulai dan mengakhiri suatu pekerjaan, tahu membedakan kapan waktu istirahat dan kapan waktu bekerja serius, menyelesaikan suatu pekerjaan yang telah ditetapkan merupakan contoh dari bentukbentuk kepatuhan terhadap aturan standar.

c. Aspek pemberian hukuman jika terjadi pelanggaran

Disiplin sering dikonotasikan sebagai hukuman namun tidak semua ketentuan disiplin berbentuk hukuman. Hukuman hanya diberikan ketika seseorang karyawan melakukan pelanggaran. Pemberian hukuman juga dilakukan sesuai jenis dan tingkat pelanggaran yang dilakukan. Dalam hal ini berarti kedisiplinan memiliki tiga aspek penting, antara lain yaitu sikap mental, pemahaman yang baik mengenai aturan perilaku, dan sikap kelakuan yang menunjukkan kesungguhan hati untuk menataati aturan yang ada.

\section{METODE PENELITIAN}

Penelitian ini menggunakan pendekatan kualitatif. Dimana metode ini meneliti obyek secara alamiah (tidak dibuat-buat atau kondisi secara sengaja dibuat seperti itu). Dalam metode ini peneliti terlibat dalam pengalaman secara terus-menerus dan berkelanjutan dengan para partisan (Sugiono, 2017). Yang nantinya selama penelitian peneliti akan menemukan masalah strategis, etis dan personal. 


\section{Nunun Nurhajati, Cicik Malinda}

Dampak Penerapan Absensi Finger Print Dengan Kedisiplinan Pegawai Di Uptd Pasar Kauman Kabupaten Tulungagung

Penelitian metode ini melibatkan prosedur-prosedur dan pertanyaan pertanyaan dari para partisan. Alasan kenapa menggunakan pendekatan kualitatif, karena penelitian ini membutuhkan data yang bersumber dari tanggapan dari narasumber langung. Selain itu, Karena penelitian ini membutuhkan kondisi alami dari lapangan.

Sedangkan jenis penelitian ini adalah deskriptif analitik yang berarti data diperoleh dari hasil pengamatan, wawancara, pemotretan, analisis dokumen, catatan lapangan yang kemudian dianalisis dengan memperkaya informasi, mencari hubungan, membandingkan, menemukan pola atas dasar data aslinya. Data utama dari penelitian ini berbentuk kata-kata dan tindakan yang tertulis.

\section{HASIL DAN PEMBAHASAN}

Pasar tradisional Kauman merupakan pasar rakyat yang berada di Kecamatan Kauman Kabupaten Tulungagung. Pasar Kauman sering disebut sebagai pusat perekonomian Kecamatan Kauman karena segenap warga beberapa desa di sekitarnya turut mendukung, melengkapi hiruk-pikuk berbagai jenis transaksi ekonomi baik jasa maupun sejumlah komoditi. Hal ini menorehkan simbol pasar Kauman sebagai sebuah pasar induk. Selain terletak di pinggir jalan raya utama, pasar ini juga diapit oleh bangunan kompleks pertokoan sepanjang kurang lebih 100 meter dari arah Selatan ke Utara. Pedagang pasar ini juga terbagi atas Pedagang jenis Pertokoan/Kios, Pedagang Los, dan Pedagang Oprokan.

Pedagang jenis Pertokoan menempati deretan terdepan menghadap jalan, berbagai macam dagangan. Sebagian yang lain berada di dalam pasar dengan klasifikasi luas yang berbeda. Berdasarkan hasil penelitian, dampak Penerapan Absensi Finger Print Bagi Peningkatan Kedisiplinan Pegawai di UPTD Pasar Kauman Kabupaten Tulungagung antara lain bisa dilihat dari beberapa indikator yaitu sebagai berikut: 


\section{a. Ketepatan Jam Kerja}

Dengan menggunakan ketepatan waktu, dimungkinkan untuk menetapkan dalam istilah persentase berapa jam atau menit yang dibutuhkan untuk istirahat, berapa banyak untuk pekerjaan yang bermanfaat, dan berapa banyak yang diperlukan untuk mempersiapkan proses kerja. Berdasarkan hasil wawancara dengan Kepala UPT Dinas Pasar Kauman Tulungagung (Bapak Eko Setiyo Rahayu, S.Sos.) yang mengatakan:

"Dulu saat masih manual meskipun saya sudah tegas, tetapi masih ada saja sejumlah Pegawai Negeri Sipil yang dating terlambat dan pulang pun cepat dengan berbagai alasan. Memang, saat sedang tidak jam kerja pertama dan terakhir ataupun tugas penting. Tetapi itu tidak sesuai jadwal yang ditetapkan. Masalahnya dulu kan tidak tertera jam datang dan pulang lagian adakalanya saya dinas keluar dan tidak melihat kehadiran mereka".(Wawancara, 2 Juni 2020, jam 10.30 WIB)".

Berdasarkan hasil wawancara dengan Kepala pasar di atas bisa disimpulkan bahwa dengan penerapan absen elektronik, meskipun diawasi atau tidak diawasi, mereka (PNS) sudah sadar bahwa ketika datang terlambat lewat dari waktu yang ditentukan tidak akan terekam di mesin absen elektronik. Demikian juga ketika pulang kurang dari waktu yang ditentukan, mesin absen tidak bias merekam.

Adapun toleransi keterlambatan waktu untuk melakukan absen elektronik di di UPT Dinas Pasar Kauman Tulungagung adalah 30 menit. Lebih lanjut Kepala Tata Usaha juga memastikan Pegawai Negeri Sipil memahami apa yang menjadi tanggung jawab masingmasing pegawai menjadi salah satu hal terpenting. Pada umumnya, Pegawai Negeri Sipil yang sudah diberi toleransi dari Pemerinrah Daerah seharusnya tidak menyepelekannya.

Ini sesuai dengan pernyataan Hanifah (2013) menyatakan bahwa kedisiplinan merupakan suatu hal yang sangat mutlak dalam kehidupan manusia, karena 


\section{Nunun Nurhajati, Cicik Malinda}

Dampak Penerapan Absensi Finger Print Dengan Kedisiplinan Pegawai Di Uptd Pasar Kauman

Kabupaten Tulungagung

seorang manusia tanpa disiplin yang kuat akan merusak sendi-sendi kehidupannya, yang akan membahayakan dirinya dan manusia lainnya, bahkan alam sekitarnya.

\section{b. Kepatuhan pegawai}

Kepatuhan Pegawai Negeri Sipil (PNS) dalam mengikuti setiap kegiatan sangat diperlukan dalam mendukung lancarnya pelaksanaan pekerjaan pada suatu organisasi. Hal ini mendorong gairah kerja, semangat kerja, dan terwujudnya tujuan organisasi. Guna mewujudkan tujuan organisasi yang harus segera dibangun dan ditegakkan adalah kedisiplinan pegawainya.

Berdasarkan hasil wawancara dengan Kepala UPT Dinas Pasar Kauman Tulungagung mengatakan bahwa Pegawai Negeri Sipil di UPT Dinas Pasar Kauman Tulungagung sendiri dalam pelaksanaan setiap kegiatan terdapat pegawai yang tidak mengikuti kegiatan, hal tersebut juga dikarenakan terdapatnya pegawai yang terlambat dating ke kantor, sehingga secara otomatis pegawai tersebut tidak dapat mengikuti kegiatan, hal tersebut dikarenakan ada Pegawai Negeri Sipil terlambat datang, sehingga dia tidak dapat melakukan kegiatan di pasar seperti sosialisasi atau yang lainnya yang berkaitan dengan kedinasan.

Inisesuai dengan pernyataan Unaradjan (2013:9) menyatakan bahwa Disiplin merupakan latihan waktu dan batin agar segala perbuatan seseorang sesuai dengan peraturan yang ada. Dan disiplin berhubungan dengan pembinaan, pendidikan, serta perkembangan pribadi manusia. Yang menjadi sasaran pembinaan dan pendidikan ialah individu manusia dengan segala aspeknya sebagai suatu keseluruhan. Semua aspek tersebut diatur, dibina, dan dikontrol hingga pribadi yang bersangkutan mampu mengatur diri sendiri. 
c. Penyelesaian Tugas

Agar menjadi pegawai yang handal, profesional, dan bermoral, seorang Pegawai Negeri Sipil (PNS) harus mampu memperbaiki sikap mental disiplin kerja dan termotivasi untuk meningkatan efektifitas kinerja. Beberapa indikator yang harus ditingkatkan antara lain meliputi pelaksanaan disiplin kerja dengan mematuhi dan menaati peraturan disiplin dan disiplin kerja, rasa tanggungjawabdalam menyelesaikanpekerjaan, sertaproduktivitaskerja yang berdaya guna.

Berdasarkan hasil wawancara dengan Kepala Tata Usaha UPT Dinas Pasar Kauman Tulungagung bahwa Pegawai Negeri Sipil (PNS) dalam melaksanakan tugas yang handal, professional, dan bermoral tersebut harus melaksanakan tugas sesuai konsep yang ada, meskipun terkadang terdapat kendala yang menyebabkan pekerjaan tidak berjalan sesuai dengan konsepnya, hal tersebut dikarenakan terkadang pegawai menerima disposisi tugas yang tidak sesuai dengan tugas dari seorang Pegawai Negeri Sipil (PNS).

Sesuai dengan penyertaan Santoso (2015) menyatakan bahwa mentaati dan tidak menyimpang dari tata tertib atau aturan yang berlaku merupakan suatu bentuk tindakan kedisiplinan. Santoso juga menyatakan bahwa kedisiplinan adalah sesuatu yang teratur, misalnya disiplin dalam menyelesaikan pekerjaan berarti bekerja secara teratur.

\section{d. Mematuhi Peraturan Dalam Bekerja}

Dalam pelaksanaan peraturan-peraturan di UPT Dinas Pasar Kauman Tulungagung, masih terdapat pelanggaran-pelanggaran yang dilakukan sehingga menunjukkan ketidakdisiplinan pegawai. Dalam rangka upaya meningkatkan kedisiplinan Pegawai Negeri Sipil (PNS) tersebut, Pemerintah telah menerbitkan Peraturan tentang disiplin Pegawai Negeri Sipil (PNS), yaitu mulai dari Peraturan Pemerintah Nomor 11 Tahun 1952 tentang 


\section{Nunun Nurhajati, Cicik Malinda}

Dampak Penerapan Absensi Finger Print Dengan Kedisiplinan Pegawai Di Uptd Pasar Kauman Kabupaten Tulungagung

Hukuman Jabatan, Peraturan Pemerintah Nomor 6 Tahun 1974 tentang Pembatasan Kegiatan Pegawai Negeri Sipil Dalam Usaha Swasta, yang terakhir adalah dikeluarkannya Peraturan Pemerintah Nomor 11 Tahun 2017 tentang Manajemen Pegawai Negeri Sipil

Berdasarkan hasil wawancara dengan Kepala UPT Dinas Pasar Kauman Tulungagung tersebut bahwa tujuan pemerintah mengeluarkan peraturan adalah supaya Pegawai Negeri Sipil (PNS) bias menjalankan tugas sesuai tugas pokok dan fungsinya. Namun dalam kenyataannya, peraturan yang telah diterbitkan pemerintah di atas tidak dapat menekan pelanggaran disiplin yang dilakukan Pegawai Negeri Sipil (PNS). Masih banyak ditemukan Pegawai Negeri Sipil (PNS) yang tidak disiplin dalam bekerja, kurangnya kesadaran untuk menyelesaikan tugas, serta kurangnya rasa tanggungjawab terhadap pekerjaannya.

Di dalam melaksanakan absensi dengan Finger Print, juga terdapat faktor -faktor yang mendukung dan jua menghambat. Faktor pendukungnya adalah sarana dan prasarana. Seperti kita ketahui bahwa Keberhasilan implementasi kebijakan sangat didukung oleh sarana dan prasara yang baik maupun sumber daya pendukung lainnya. Mengingat pentingnya sarana prasarana dalam kegiatan absensi elektronik, maka absensi dengan Finger Print akan lebih terbantu dengan dukungan sarana prasarana yang baik dan lancar. Lebih lanjut salah satu Pegawai Negeri Sipil UPT Dinas Pasar Kauman Tulungagung (Bapak Lumoyo) yang mengatakan:

"Guna mendukung dampak penerapan kebijakan absen elektronik sidik jari (finger print) Pegawai Negeri Sipil (PNS) di UPT Dinas Pasar Kauman Tulungagung, pihak Dinas tidak hanya menyiapkan sarana absen yaitu absen elektronik sidik jari atau finger print dengan kualitas yang baik tetapi pihak UPT harus bias mengelola dengan baik, sehingga dalam melakukan absensi akan berjalan dengan lancar".(Wawancara tanggal 11 Juni 2020, jam 13.45 WIB.) 
Sesuai dengan pernyataan Faisal (2015), pelaksanaan pengisian daftar hadir atau absensi secara manual (hanya berupa buku daftar hadir), akan menjadikan penghambat bagi organisasi untuk memantau kedisiplinan pegawai dalam hal ketepatan waktu kedatangan dan jam pulang setiap hari.

Faktor lainnya yang mendukung adalah karena adanya peraturan dari dinas. Peraturan merupakan patokan yang dibuat untuk membatasi tingkah laku seseorang dalam suatu lingkup Organisasi tertentu yang jika melanggarakan dikenakan hukuman/sangsi. Berdasarkan wawancara dengan Kepala UPT Dinas Pasar Kauman Tulungagung bahwa sejak ditetapkan Peraturan Daerah Kabupaten Tulungagung Nomor 9 Tahun 2013 tentang Peraturan Daerah (PERDA) tentang Disiplin Pegawai Negeri Sipil (PNS, membawa konsekuensi banyaknya Pegawai Negeri Sipil (PNS) yang dijatuhkan hukuman disiplin, karena melanggar kewajiban dan larangan dalam hal ini adalah pelaksanaan absensi elektronik sidik jari (finger print).

Faktor yang ketiga adalah sumber daya manusia. Untuk menciptakan Sumber Daya Manusia (SDM) yang berkualitas maka diperlukan disiplin pegawai. Disiplin pegawai merupakan suatu hal yang penting untuk diperhatikan dalam keberlangsungan suatu organisasi, karena tingkat disiplin pegawai sangat mempengaruhi keberhasilan organisasi secara keseluruhan terutama pada UPT Dinas Pasar Kauman Tulungagung. Hasil wawancara dengan Kepala UPT Dinas Pasar Kauman Tulungagung ada beberapa point penting dalam meningkatkan Sumber Daya Manusia (SDM) yang berkualitas yaitu: (a) ketepatan waktu datang, (b) ketepatan waktu pulang, dan (c) Ketepatan waktu pegawai dalam mengerjakan tugas.

Ada faktor pendukung pasti juga ada faktor penghambatnya. Pertama jaringan internet. Suatu instansi maupun perusahaan harus memiliki jaringan internet yang bagus, hal ini sangat membantu dalam suatu pekerjaan pada era modern ini. 


\section{Nunun Nurhajati, Cicik Malinda}

Dampak Penerapan Absensi Finger Print Dengan Kedisiplinan Pegawai Di Uptd Pasar Kauman Kabupaten Tulungagung

Hasil wawancara dengan Kepala UPT Dinas Pasar Kauman Tulungagung bahwa permasalah yang terjadi tidak hanya di UPT Dinas Pasar Kauman Tulungagung, tetapi di UPTD-UPTD yang lain juga sama diantaranya adalah: (a) Identifikasi Sensor Lambat, (b) Hang Macet, (c) Tidak Menerima Scan, (d) Jam dan Tanggal Tidak Sesuai, (e) Tidak Bisa Terkoneksi dengan Komputer, dan semuanya itu dipermasalahkan karena koneksi internet yang kadang buruk. Dan semua permasalan itu diperhatikan oleh Pemerintah Daerah supaya absensi elektronik sidik jari (finger print) dapat berjalan dengan lancar. Kedua, scan berulang-ulang dalam satu waktu. Kebiasaan buruk yang dilakukan pegawai dalam melakukan absensi sidik jari (finger print) adalah ketika absensi dilakukan secara berulangulang, hal ini dapat memicu alat finger print akan mengalami hang atau macet. Ini dilakukan pegawai karena kurangnya pengetahuan terhadap alat finger print.

Hasil wawancara dengan Kepala UPT Dinas Pasar Kauman Tulungagung bahwa setiap instansi pastinya ingin memiliki pegawai yang mampu untuk selalu dapat memberikan yang terbaik bagi instansi, termasuk pegawai yang dapat menunjukkan perilaku sehari-hari yang profesional di lingkungan kerja. Pada kenyataannya, masih sangat sering dijumpai pegawai yang melakukan kesalahan baik disengaja maupun tidak dalam hal absensi. Terlepas dari sengaja atau tidaknya perilaku tersebut, kebiasaan buruk yang dilakukan pegawai terkait scan absensi bisa menimbulkan dampak kerugian baik langsung maupun tidak langsung.

\section{KESIMPULAN}

Dampak Penerapan Absensi Finger Print Bagi Peningkatan Kedisiplinan Pegawai di UPTD Pasar Kauman Kabupaten Tulungagung, antara lain: Ketepatan jam kerja, bukan hanya tentang tiba di kantor pada waktu yang tepat setiap pagi, namun juga tidak terlambat kembali ke kantor saat jam istirahat sudah habis. Kepatuhan pegawai, sikap yang menunjukkan ketaatan, kesetiaan, keteraturan dan ketertiban pada peraturan istansi terkait. 
PUBLICIANA : JURNAL ILMU SOSIAL DAN ILMU POLITIK

VOLUME 14 NO 1

ISSN : 1979 - $0295 \mid$ E-ISSN : 2502 - 7336

$\overline{\text { Penyelesaian tugas, sikap pegawai yang memiliki kedisiplinan dalam menggunakan waktu }}$ baik untuk memulai dan mengakhiri pekerjaan. Mematuhi peraturan dalam bekerja, sikap pegawai dalam mentaati peraturan agar manajemen serta operasional sehari-hari di instansi dapat berjalan dengan baik. Terkadang, masih ditemui masalah yang dialami oleh pegawai saatmelakukan absen, terutama untuk pegawai yang memiliki jari yang sensitif maupun pegawai yang jarinya terkadang basah karena keringat. Biasanya mesin Finger Print akan mengalami masalah deteksi dikarenakan hal tersebut. 


\section{Nunun Nurhajati, Cicik Malinda}

Dampak Penerapan Absensi Finger Print Dengan Kedisiplinan Pegawai Di Uptd Pasar Kauman

Kabupaten Tulungagung

\section{DAFTAR PUSTAKA}

Adi, S. 2015. Development of a virtual laboratory on topic excretory system to improve learning motivation of students xi grade at state senior high school 2 bondowoso. Artikel Ilmiah Mahasiswa, (1), hlm. 1-8.

Alex, Nitisemito. 2015. Manajemen Sumber Daya Manusia. Bandung: Pustaka setia.

Amir, Mohammad Faisal, 2015. Memahami Evaluasi Kinerja Karyawan, Konsep, dan Penilaian Kinerja di Perusahaan. Jakarta: Mitra Wacana Media.

Aunurrahman. 2014. Belajar dan Pembelajaran. Bandung: Alfabeta.

Bangun, Wilson. 2012. Manajemen Sumber Daya Manusia. Jakarta: Erlangga.

Bintoro dan Daryanto. 2017. Manajemen Penilaian Kinerja Karyawan. Cetakan 1. Yogyakarta: Gava Media.

Cahyana dan Maolani, R. A. 2015. Metodologi Penelitian Pendidikan.Jakarta: PT. Raja GrafindoPersada.

Djunaidi Ghony dan Fauzan. 2014. Metodologi Penelitian Kualitatif. Jogjakarta: Ar-. Ruzz Media.

Dolet,Unaradjan. 2013. Manajemen Disiplin. Jakarta: PT. Gramedia Widiasarana Indonesia. 
PUBLICIANA : JURNAL ILMU SOSIAL DAN ILMU POLITIK

VOLUME 14 NO 1

ISSN : 1979 - 0295 | E-ISSN : $2502-7336$

$\overline{\text { Edy, Sutrisno. 2016. Manajemen Sumber Daya Manusia, Kencana Prenada. Jakarta: Media }}$ Group.

Gaol, L. Jimmy. 2014. Manajemen Sumber Daya Manusia. Jakarta: Grasindo.

Gibson, R L; Mitchell, Marianne H. 2011. Bimbingan dan Konseling (Edisi. Indonesia-Edisi ke Tujuh). Yogyakarta: Pustaka Pelajar.

Hani, Syafrida. 2015. Teknik Analisa Laporan Keuangan. Medan: UMSU PRESS

Handoko, T. Hani. 2008. Manajemen Personalia dan Sumber Daya Manusia. Yogyakarta: Liberty

Hanifah, Oktita Earning. 2013. Pengaruh Struktur Corporate Governance dan Financial Indicators terhadap Kondisi Financial distress Distress (Studi pada Perusahaan Manufaktur yang Terdaftar di Bursadi Bursa Efek Indonesia Tahun 2008-2010). Skripsi, Fakultas Ekonomi, Universitas Diponegoro.

Hasibuan, Malayu. 2014. Manajemen Sumber Daya Manusia. Jakarta: Bumi. Aksara.

Hurlock, E. B. 2012. Psikologi Perkembangan, Suatu Pendekatan Sepanjang. Rentang Kehidupan (terjemahan). Jakarta: Erlangga.

Kenneth, T. 2012. The Bacterial Flora of Humans Todar's Online Textbook of Bacteriology. Madison, Wisconsin. 


\section{Nunun Nurhajati, Cicik Malinda}

Dampak Penerapan Absensi Finger Print Dengan Kedisiplinan Pegawai Di Uptd Pasar Kauman Kabupaten Tulungagung

Maisaroh, Rostieningsih. 2010. Peningkatan Hasil Belajar Siswa dengan Menggunakan Metode Pembelajaran Active Learning Tipe Quiz Team Pada Mata Pelajaran Keterampilan Dasar Komunikasi di Smk Negeri 1 Bogor. Jurnal Ekonomi \& Pendidikan, Volume 8 Nomor 2. November.

Miles,M.B, Huberman,A.M, dan Saldana,J. 2014. Qualitative Data Analysis, A Methods Source book, Edition 3. USA: Sage Publications. Terjemahan Tjetjep Rohindi Rohidi, UI-Press.

Muhaimin, dkk. 2010. Manajemen Pendidikan dalam Aplikasinya dalam penyusunan. Rencana Pengembangan Sekolah / Madrasah. Jakarta: Kencana Prenada.

Nur, Ahmad Rofi, 2012. Pengaruh Disiplin Kerja dan Pengalaman Kerja terhadap Prestasi Kerja Pegawai pada Departemen Produksi PT. Leo Agung Raya Semarang, Jurnal Ilmu Manajemen dan Akuntansi Terapan, Vol 3 Nomor 1, Mei 2012.

Prastowo, Andi. 2011. Metode Penelitian Kualitatif dalam Perspektif Rancangan. Penelitian. Jogjakarta: Ar-Ruzz Media.

Rahman, MasykurArif. 2011. Pentingnya Disiplin Belajar. Jakarta: Rineka. Cipta.

Robbins, Stephen P. dan Coulter, Mary. 2010. Manajemen Edisi Kesepuluh. Jakarta: Erlangga.

Rohman, Arif. 2011. Memahami Pendidikan dan Ilmu Pendidikan. Yogyakarta: Laks Bang Mediatama. 
PUBLICIANA : JURNAL ILMU SOSIAL DAN ILMU POLITIK

VOLUME 14 NO 1

ISSN : 1979 - $0295 \mid$ E-ISSN : $2502-7336$

$\overline{\text { Sangadji, Etta Mamang \& Sopiah. 2010. Metodologi Penelitian Pendekatan. Praktis dalam }}$ Penelitian. Yogyakarta: ANDI.

Santoso, AW Yulianto. MATRIK: Jurnal Manajemen, Teknik Informatika dan Rekayasa Komputer 16 (2), 65-75, 20 